\title{
NEW MINIMUM WAGE RESEARCH: SYMPOSIUM INTRODUCTION
}

\author{
RONALD G. EHRENBERG*
}

$\mathrm{A}$ FTER almost a decade of "benign" neglect, the Fair Labor Standards Act (FLSA) was amended in November 1989. ${ }^{1}$ The amendments increased the federal minimum wage from $\$ 3.35$ to $\$ 3.80$ an hour, effective April 1, 1990, and then to $\$ 4.25$ an hour, effective April 1, 1991 . Among the amendments' other provisions was the adoption of a subminimum or training wage for teenagers, which allows employers to pay teenagers $85 \%$ of the prevailing minimum wage during their first six months of employment. The latter provision, however, contains a "sunset" clause; unless legislation is passed to extend the subminimum wage, it will end on March 31, 1993.

The Fair Labor Standards Amendments of 1989 also require the Secretary of Labor to report to Congress no later than March 1,1993 , on the extent to which employers have made use of the subminimum wage, the impact of the subminimum wage on employment opportunities for both experienced and inexperienced workers, and its impact on the nature and duration of training offered to workers. Together, the sunset clause, the reporting requirement, and the fact that the federal minimum wage has been pegged at $\$ 4.25$ an hour since April 1, 1991, almost guarantee that proposals to amend the $F L S A$ will appear in Congress in the near future.

The passage of the 1989 FLSA amendments stimulated a new wave of research

\footnotetext{
* Irving M. Ives Professor of Industrial and Labor Relations and Economics, Cornell University, and Research Associate, National Bureau of Economic Research.

${ }^{1}$ Fair Labor Standards Amendments of 1989, Public Law 101-157 [HR 2710], November 1989.
}

on the effects of minimum wage legislation, and five of the resulting papers are gathered together in this symposium. Four of these are revisions of papers that were presented at the ILR-Cornell Institute for Labor Market Policies/Princeton University Industrial Relations Section Conference, "New Minimum Wage Research," which was held at Cornell University on November 15, 1991.2 These papers, as well as the fifth paper, which was contributed by one of the conference participants after the conference was concluded, have all been subject to a refereeing process. I hope that assembling these papers here will enhance their usefulness in future policy debate.

Most, but not all, prior research on the employment effects of minimum wage changes made use of either aggregate time-series data or state cross-section data. The time-series studies exploited the fact that the minimum wage varies over time relative to other wages both because of changes in the minimum wage and because of changes in other wages. The cross-section studies exploited the fact that, although the federal minimum wage is constant across states at a given time, minimum wage levels under state laws and

\footnotetext{
${ }^{2}$ The conference was organized by Alan Krueger of Princeton and myself. It was attended by a total of 35 individuals spanning academia, liberal-oriented (Economic Policy Institute) and conservative-oriented (American Enterprise Institute) Washington "think-tanks," federal executive and legislative staffs, and several state agencies. One of the purposes of the conference was to honor Donald Cullen for his years of service to the profession as Editor of the Industrial and Labor Relations Review. Coincidentally, Cullen himself was an early contributor to the debate over minimum wage laws (see Cullen 1961).
}

Industrial and Labor Relations Review, Vol. 46, No. 1 (October 1992). (C) by Cornell University. $0019-7939 / 92 / 4601 \$ 01.00$ 
their coverage vary across states, as do the prevailing values of other wages. On balance, these prior studies concluded that, ceteris paribus, a $10 \%$ increase in the minimum wage would be associated with a $1 \%$ to $3 \%$ decrease in teenage employment (Brown 1988).

Four of the symposium papers reexamine the issue of employment effects of minimum wage changes, and the authors of these papers have taken seriously Richard Freeman's advice that labor economists should search for natural experiments and use these to evaluate hypotheses (Richard Freeman 1989:x). Lawrence Katz and Alan Krueger survey fast-food restaurants in Texas that were in business both prior to and after the 1991 change in the federal minimum wage law. They ask if those firms most likely to be affected by the minimum wage increase (those that employed relatively more low-wage workers) suffered the greatest employment losses after the increases. David Card's first contribution uses Current Population Survey data to see if teenage employment declined more after the 1990 federal minimum wage increase in states in which relatively more teenagers should have been affected by the change. This paper exploits the fact that prior to the 1990 change in the federal minimum wage, the fraction of teenagers earning between $\$ 3.35$ and $\$ 3.80$ an hour varied across states from less than $10 \%$ to more than $50 \%$.

Card's second paper focuses on the July 1988 increase in the California state minimum wage from $\$ 3.35$ to $\$ 4.25$ an hour, which predated the increase in the federal minimum. He contrasts changes in teenage employment in California with changes in teenage employment in "similar" nearby states that did not change their state minimum wage rates at the same time. Finally, David Neumark and William Wascher employ panel data that take account of changes in state minimum wage levels and coverage during the 1977-78 period to analyze the employment effects of minimum wage changes.

Quite dramatically, Katz and Krueger's paper and both of Card's papers find no evidence that increases in minimum wages cause employment declines. In contrast, Neumark and Wascher do find negative employment effects for some of their econometric specifications, and they argue that these specifications are the preferred ones in their paper.

How can one reconcile these divergent findings? At least three possible explanations exist. First, Katz and Krueger acknowledge they are analyzing employment changes at firms that survive, so their analysis can tell us nothing about the effects of the minimum wage increase on the probability that an established firm survives or the probability that a new firm is created. $^{3}$ Increases in the minimum wage may decrease both "survival" and "creation" probabilities and adversely influence employment via these routes.

Second, Neumark and Wascher's data span an earlier period of time than the data used in the other studies. During most of the earlier period, the value of the minimum wage relative to both prices and other wages was higher than it was during the period the other studies span, as was the proportion of workers earning near or at minimum wage rates. The magnitude of the employment loss caused by a given percentage increase in the minimum wage may well depend on the initial relative value of the minimum wage, as well as the number of workers earning at or near the minimum wage.

Third, Neumark and Wascher present evidence that estimates of minimum wage effects depend crucially on the specific statistical model used. For example, when they apply the statistical approach Card used in both of his papers to their own data and preferred equations, they find (similarly to Card) no statistically significant evidence of negative effects of minimum wages on employment. They argue, however, that some specification tests they conduct (relating to the possibility that lagged minimum wage effects exist) suggest that their own statistical approach, which did show negative effects

\footnotetext{
${ }^{3}$ Cullen (1961:10) noted this same point.
} 
of minimum wages on employment, is preferable.

Although ultimately it is up to the reader to decide whose estimates are to be preferred, it is significant that none of the studies suggest that at current relative values of the minimum wage, large disemployment effects would result from modest future increases in the minimum wage-increases up to, say, $10 \%$. In this sense, all the findings are very consistent.

The symposium papers also address a variety of other issues. For example, Ralph Smith and Bruce Vavrichek focus on the earnings mobility of workers who, in an initial survey, were earning the minimum wage. Data from the Survey of Income and Program Participants during the mid-1980s suggest that although most of these workers who were still employed a year later were earning higher wagestypically almost $20 \%$ more-a substantial fraction remained "trapped" at the minimum wage. These latter people, who tend to be part-time workers, older workers, and workers without high school diplomas, are the workers who are most likely to benefit from minimum wage increases, although one suspects they are also the group whose employment might be most adversely affected.

To take two other examples, several papers address issues relating to subminimum wage laws. Katz and Krueger find that less than $5 \%$ of the employers in their fast-food sample took advantage of the new federal subminimum provision. In contrast, Neumark and Wascher's analysis, which takes account of subminimum wage provisions in state minimum wage laws, yields some evidence that these provisions moderate the disemployment effects of minimum wage increases. Several papers also address the effects of minimum wage increases on educational decisions. No evidence is found either by Neumark and Wascher or by Card that such increases adversely affect aggregate school enrollment rates. ${ }^{4}$

These papers do not exhaust the set of research questions to which policy-makers need answers. For example, we learn little from them as a group about the income distribution consequences of minimum wage changes for different racial or ethnic groups or about whether subminimum wages for teenagers have adverse effects for any adult groups. Nonetheless, one can safely predict that these papers will be cited often in future policy debates over minimum wage legislation.

\footnotetext{
${ }^{4}$ Research that Alan Marcus and I conducted over a decade ago suggested that increases in minimum wages affect the distribution of educational outcomes. In particular, we found that increases in the minimum wage increase the educational levels of teenagers from middle- and upper-income families and decrease the educational levels of teenagers from low-income families (Ehrenberg and Marcus 1980, 1982). Such distributional effects should interest policy-makers as much as does the lack of aggregate educational effects found by this symposium's authors.
}

\section{REFERENCES}

Brown, Charles. 1988. "Minimum Wage Laws: Are They Overrated?" Journal of Economic Perspectives, Vol. 2, No. 3, pp. 133-46.

Cullen, Donald E. 1961. Minimum Wage Laws. Ithaca: New York State School of Industrial and Labor Relations, Cornell University.

Ehrenberg, Ronald G., and Alan J. Marcus. 1982. "Minimum Wages and Teenagers' EnrollmentEmployment Outcomes: A Multinomial Logit
Model." Journal of Human Resources, Vol. 17, No. 1, pp. 39-58.

1980. "Minimum Wage Legislation and the Educational Outcomes of Youths." In Ronald G. Ehrenberg, ed., Research in Labor Economics, Vol. 3. Greenwich, Conn.: JAI Press, pp. 61-93.

Freeman, Richard B. 1989. Labor Markets in Action: Essays in Empirical Economics. Cambridge, Mass.: Harvard University Press. 